\title{
Pattern of pulmonary function test in rheumatoid arthritis patients
}

\author{
Haithem J. kadhum1, Ali N. Al hamza' \& Ahmed B Abdualwahid ${ }^{3}$
}

\section{ABSTRACT}

Background: Rheumatoid arthritis (RA) is a chronic inflammatory disease characterized by a painful symmetrical peripheral polyarthritis. Extra-articular involvement in RA is a common condition. Pulmonary involvement occurs in 20 to $67 \%$ of RA patients and it is responsible for about $10-20 \%$ of mortality in RA patients.

Objectives: To evaluate the extent and pattern of pulmonary involvement in RA patients by using spirometry.

Methods: A case control study conducted at the rheumatology unit of Al Sader teaching hospital, forty RA patients [33(82.5\%) female and $7(17.5 \%)$ male] and sixty apparently healthy subjects $\{50(83.3 \%)$ female and $10(16.7 \%)$ male were included in the study. All subjects had subjected to a pulmonary function test (PFT) for pulmonary function evaluation using MIR spirolab III. Measured and predicted forced vital capacities (FVC), forced expiratory volume in the first second (FEV1) and FEV1 / FVC ratio were considered as the parameters in this study for both groups.

Results: Nine patients were found to have a restrictive pattern of pulmonary function test, while obstructive pattern was found in only one patient. On the other hand, the pulmonary function tests were normal in all of sixty healthy control. The mean of FEV1 in patient group ( $2.07 \pm 0.56 \mathrm{~L})$ and of FEV1\% $(95.8 \% \pm 25.2)$ are significantly lower than those in the control group $(2.46 \pm 0.65 \mathrm{~L} ; 105.3 \% \pm 13.09)$. In addition, mean FVC in the patient group $(2.35 \pm 0.62 \mathrm{~L})$ and its mean percentage $(92 \% \pm 22.68)$ showed a clear significant reduction compared to those in control group $(2.71 \pm 0.67 \mathrm{~L} ; 100.53 \pm 12.12)$. No significant difference $(P=\mathbf{0 . 1 7 3})$ has been observed in FEV1 / FVC ratio between patient $(88.17 \pm 7.47)$ and control group $(89.87 \pm 4.99)$.

Conclusions: Different pattern of pulmonary function abnormalities could be manifested in RA patients and the restrictive pattern represents the most common feature. Spirometry is indicated as a baseline assessment and for follow up of RA patient to enhance early detection and management of the pulmonary involvement.

Keywords: Rheumatoid arthritis, pulmonary function test.

$$
\text { انماط فحص وظائف الرئة لدى المرضى المصابين بالتهاب المفاصل الروماتزمي }
$$

التهاب المفاصل الروماتزمي هو مرض التهابي مزمن يسبب التهاب المفاصل الطرفية المتناظرة المؤلم. اصابة اعضاء اخرى في الجسم غير المفاصل

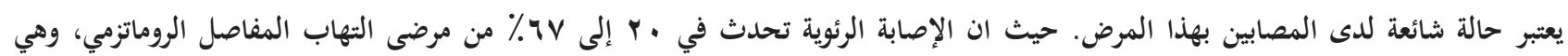
مسؤولة عن حوالي • 1- • ٪ ٪ من الوفيات لمرضى التهاب المفاصل الروماتزمي . الأهداف: لتقييم مدى ونمط الاصابات الرئوية في مرضى التهاب المفاصل الروماتزمي في مدينة بصرة عن طريق فحص وظائف الرئة . الطريقة: الدراسة هي دراسة مقارنة بين الحالات المرضية والاصحاء واجريت في وحدة الروماتزم في مستشفى الصدر التعليمي في مدينة البصرة

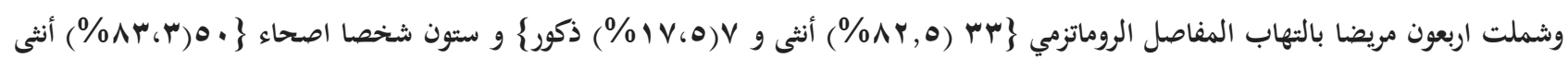

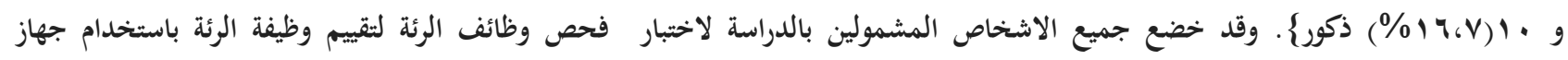
سبايرولاب حيث تم قياس حجم هواء الزفير الكلي القسري (FVC)، وحجم الزفير القسري في الثانية الأولى (FEV1)، ونسبة القيمتين (FEV1/FVC) النتائج: وجدان تسعة مرضى لديهم نمط تحددي في اختبار وظيفة الرئة، في حين تم العثور على نمط انسدادي في اختبار وظيفة الرئة في مريضة واحدة. من ناحية أخرى، كان اختبار وظيفة الرئة طبيعيا في كل الاشخاص الاصحاء. وكانت قيمة متوسط FEV1 في مجموعة المرضى (V • . 


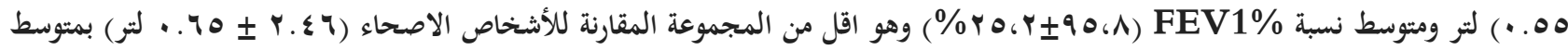

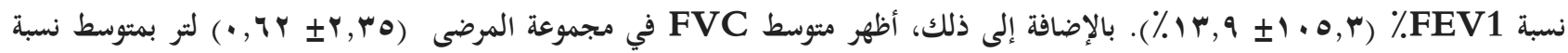

$$
\begin{aligned}
& \text { Y \% بانخفاض واضح مقارنة مع مجموعة المقارنة للأشخاص الاصحاء الذين كان متوسط قيمة YV I Y.V) FVC. . . لتر) ومتوسط نسبة }
\end{aligned}
$$

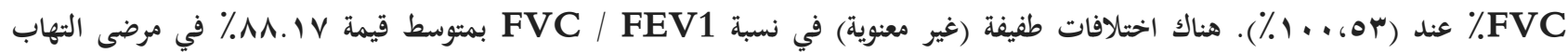

$$
\begin{aligned}
& \text { المفاصل الروماتزمي و A9.AV٪ في المجموعة المقارنة للأشخاص الاصحاء. } \\
& \text { الاستنتاجات: انماط مختلفة من اصابات الرئة يمكن أن تظهر لدى مرضى التهاب المفاصل الروماتزمي ويمثل النمط المحدد الاصابة الأكثر شيوعا. } \\
& \text { ونتيجة لذلك يوصى بأجراء فحص وضائف الرئة باعتباره فحص اساسي لمرضى التهاب المفاصل الراتزمي لتعزيز الكشف المبكر للإصابات الرئوية. } \\
& \text { الكلمات المغتاحية: الثهاب المغاصل الروماتنمي، فحص وظائف الئنة }
\end{aligned}
$$

\section{INTRODUCTION}

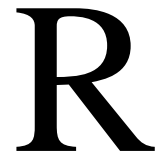
heumatoid arthritis (RA) is a chronic inflammatory disease characterized by a painful symmetrical peripheral polyarthritis. It affects multiple body organs in addition to joints' surrounding tissues and it is a leading cause of joints deformities and disabilities. Rheumatoid arthritis can develop at any age with increased incidence between 35 and 55 years of age. ${ }^{[1]}$ The prevalence of RA is approximately $0.5-1 \%$ worldwide with some variability among different populations, ${ }^{[2]}$ in Iraq it is prevalence is $1 \% .{ }^{[3]}$ Highest prevalence was recorded in Pima Indians and Chippewa Indians, whereas the lowest in Japan and China. ${ }^{[4,5]}$ Rheumatoid arthritis more commonly occurs in females than in males with age related differences. Younger onset RA female to male ratio is $4.4: 1$ while in elderly onset RA, the ratio is $1.6: 1 .^{[6]}$ Extra-articular involvement in RA is common. It was recorded in $51 \%$ of 587 RA Italian patients, and the manifestation was more common in males patients, in positive antinuclear antibody and in rheumatoid factor positive patients. ${ }^{[7]}$ In addition to rheumatoid nodules, other organs could be involved in the disease process includeing heart, lung, blood vessels, peripheral nerves as well as hematological involvement. The occurrence of extra-articular pulmonary manifestation of RA ranges from $20 \%$ in some studies to as high as $67 \%$ in others. ${ }^{[8,9]}$ Respiratory airways, pleura, lung parenchyma and vascular compartment all may be attacked by RA. ${ }^{[10]}$ In the majority of RA patients, arthritis develops first, whereas in others, pulmonary involvements could proceed or simultaneously occur with arthritis. ${ }^{[11]}$ Different forms of interstitial lung disease (ILD) occur in RA patients. They are a group of heterogenous paranchymal lung disorders characterized by their clinical, pathological and radiological features. ${ }^{[12]}$ The most commonly observed ILD in RA patients are usual interstitial pneumonia, nonspecific interstitial pneumonia and inflammatory airway disease with organizing pneumonia pattern. ${ }^{[1]}$ It has been estimated that pulmonary complications are responsible for $10-20 \%$ mortality in RA patients which is mostly caused by ILD. ${ }^{[13]}$

\section{OBJECTIVES}

The aim of this study is to evaluate the extent and abnormality of pulmonary function test in RA patients by using spirometry.

\section{SUBJECTS AND METHODS}

This study is a case control study done at the rheumatology unit in Al Sader teaching hospital during the period from June 2011 to October 2011. Spirometry was used as a diagnostic test to evaluate the type and the severity of pulmonary involvement in RA patients. After detailed and thorough medical history and physical examination, forty newly and previously diagnosed patients of both genders ( $82.5 \%$ female and $17.5 \%$ male) who met RA 2010 classification criteria as described by American College of Rheumatology were included in our study. ${ }^{[14]}$ Patients age is ranging 
from 13 to 67 (mean 48.5) years. Another sixty healthy subjects $(83.3 \%$ female and $16.7 \%$ male) were included in the study as a control group, their age ranges from 13 to 64(mean 46.1) years. Both groups were matched for height, weight and race. Patients with history of smoking, drug intake, past medical history of respiratory, cardiac and other chronic diseases were excluded from the study. All subjects had further subjected to a pulmonary function test (PFT) for their pulmonary function evaluation using spirolab- III (MIR-Italy). The test was carried out in a sitting position according to the standard protocol with the best record out of three attempts was considered for further data analysis. Measured and predicted forced vital capacity (FVC), forced expiratory volume in the first second (FEV1) and FEV1 / FVC of RA and control groups were analyzed in our study. Data analysis were carried out using SPSS software version V.20, $\mathrm{t}$ test and Fisher exact test were and the data were expressed as mean \pm standard deviation (mean $\pm \mathrm{SD}$ ), $\mathrm{P} \leq 0.05$ was considered significant.

\section{RESULTS}

(Table-1), a total of 100 individuals of both sex were selected in our study, 40 RA patients and 60 healthy individuals. As illustrated in (Table1) there was no significant difference in sex distribution between RA patients and control groups ( $\mathrm{P}=0.56$ ). The mean age of RA group $(48.5 \pm 10.4$ year) was not significantly different $(P=0.205)$ from the mean age of control group (46.1 \pm 8.2 year). Moreover, no significant difference $(\mathrm{P}=0.344)$ was observed between the mean height of RA group (159.5 \pm $7.3 \mathrm{~cm})$ and control group $(161 \pm 8.1 \mathrm{~cm})$.

Table 1. General characteristics of RA and control groups.

\begin{tabular}{|c|c|c|c|c||}
\hline \hline Group & \multicolumn{2}{|c|}{ Gender } & Age (Year) & Height (Cm) \\
\hline RA (n=40) & $7(17.5 \%)$ male & $33(82.5 \%)$ female & $48.5 \pm 10.4$ & $159.5 \pm 7.3$ \\
\hline $\begin{array}{c}\text { Control } \\
(\mathbf{n}=\mathbf{6 0})\end{array}$ & $10(16.7 \%)$ & $50(83.3 \%)$ & $46.1 \pm 8.2$ & $161 \pm 8.1$ \\
\hline P value & \multicolumn{2}{|c|}{$\mathrm{P}=0.560$} & 0.205 & 0.344 \\
\hline Applied test & \multicolumn{2}{|c|}{ Fisher exact test } & T test & T test \\
\hline
\end{tabular}

(Table-2), the mean and standard deviation of FEV1 and FVC (measured and predicted), FEV1\%, FVC\% and FEV1/FVC \% of both groups are shown in (Table-2). No significant difference has been observed with regard to predicted mean values of FEV1 and FVC between the RA and control groups, this indicates that the two groups were well matched. A highly significant $(\mathrm{P}=0.002)$ lower values of FEV1 has been observed in RA group $(2.07 \pm 0.56 \mathrm{~L})$ compared with control group $(2.46 \pm 0.65 \mathrm{~L})$. Also the FEV1\% (FEV1 measured / FEV1 predicted $\times 100)$ was significantly lower $(\mathrm{P}=0.015)$ in $\mathrm{RA}$ group (95.8 $\pm 25.2 \%)$ compared with control group $(105.3 \pm 13.09 \%)$. The FVC in RA group (2.35 $\pm 0.62 \mathrm{~L})$ is significantly lower $(\mathrm{P}=0.005)$ than that in control group $(2.73 \pm 0.67 \mathrm{~L})$. Moreover, the FVC\% is significantly reduced $(\mathrm{P}=0.02)$ in RA group $(92.28 \pm 22.68)$ compared with control group $(100.53 \pm 12.12)$. No significant difference $(\mathrm{P}=0.173)$ has been observed in FEV1/FVC\% between RA group (88.17 \pm 7.47$)$ and control group (89.87 \pm 4.99). 
Table 2. Results of FEV1, FEV1\%, FVC, FVC\% and FEV1/FVC\% in RA and control groups $($ mean \pm SD)

\begin{tabular}{||l|c|c|c||}
\hline & RA (N=40) & Control (N=60) & P value \\
\hline FEV1(L) & $2.07 \pm 0.56$ & $2.46 \pm 0.65$ & 0.002 \\
\hline FEV1 predicted (L) & $2.19 \pm 0.35$ & $2.57 \pm 1.96$ & 0.230 \\
\hline FEV1 \% (FEV1/FEV1 predicted) & $95.8 \pm 25.2$ & $105.3 \pm 13.09$ & 0.015 \\
\hline FVC (L) & $2.35 \pm 0.62$ & $2.73 \pm 0.67$ & 0.005 \\
\hline FVC predicted (L) & $2.56 \pm 0.44$ & $2.71 \pm .62$ & 0.200 \\
\hline FVC \% ( FVC /FVC predicted) & $92.28 \pm 22.68$ & $100.53 \pm 12.12$ & 0.020 \\
\hline FEV1/FVC\% & $88.17 \pm 7.47$ & $89.87 \pm 4.99$ & 0.173 \\
\hline \multicolumn{2}{|l|}{ T-test was applied } \\
\hline
\end{tabular}

(Table-3, figure-1) show abnormal pulmonary measured / FVC predicted $\%<80 \%$ ). function test in 10 of RA patients (25\%), Pulmonary function test was normal in all of 60 obstructive pulmonary disease observed in one healthy control subjects i.e. all have FEV1 / patient $(\mathrm{FEV} 1 / \mathrm{FVC} \%<70 \%)$ while restrictive $\mathrm{FVC} \%>70 \%$ and $\mathrm{FVC} \%>80 \% .^{[15]}$ pulmonary disease in nine patients (FVC

Table 3. Results of pulmonary function test in RA and control groups.

\begin{tabular}{|c|c|c|c|c|c|c|}
\hline \multirow{2}{*}{ Group } & \multicolumn{5}{|c|}{ Diagnosis } & \multirow{2}{*}{$P$ value } \\
\hline & Normal & Obstructive & & Restrictive & & \\
\hline \multirow{2}{*}{ RA $(n=40)$} & \multirow[b]{2}{*}{$30(75 \%)$} & \multirow[b]{2}{*}{$1(2.5 \%)$} & & $9(22.5 \%)$ & & \multirow{3}{*}{0.000} \\
\hline & & & $\begin{array}{c}\text { Mild } \\
6(15 \%)\end{array}$ & $\begin{array}{c}\text { Moderate } \\
2(5 \%)\end{array}$ & $\begin{array}{c}\text { Sever } \\
1(2.5)\end{array}$ & \\
\hline Control $(n=60)$ & $60(100 \%)$ & $0(0 \%)$ & \multicolumn{3}{|c|}{$0(0 \%)$} & \\
\hline Total & $90(90 \%)$ & $1(1 \%)$ & \multicolumn{3}{|c|}{$9(9 \%)$} & \\
\hline
\end{tabular}




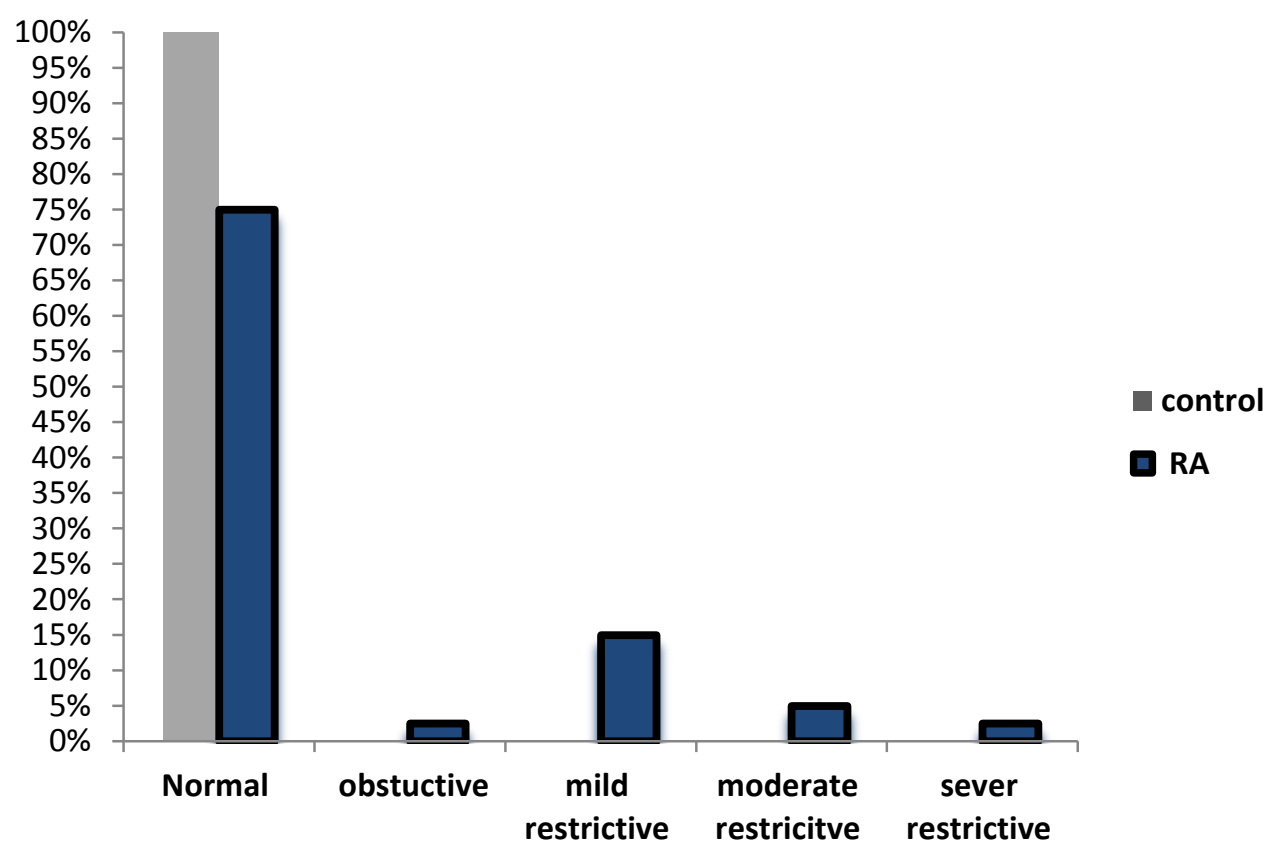

Fig 1. Results of pulmonary function test in RA and control group.

\section{DISCUSSION}

The results of this study show that the number of RA female patients exceed that of male patients seen within same time frame with a ratio reached to as high as $4.7: 1$. Although this results is a little higher value than what has been reported in the other populations, ${ }^{[3]}$ it is consistent with worldwide reports that demonstrate a tendency of RA disease for female gender. It has been found that rheumatoid arthritis improves during treatment with estrogen-containing oral contraceptives, pregnancy and with estrogen replacement therapy which suggest the role of sex hormone in developing RA in such a higher rate in females. ${ }^{[16]}$ Abnormal pulmonary function test has been found in $25 \%$ of RA patients. A restrictive pulmonary features found in nine patients $(22.5 \%)$, ranging from mild features in six patients $(15 \%)$ moderate severity in two patients $(5 \%)$ to severe restrictive features in one patient $(2.5 \%)$. Only one patient $(2.5 \%)$ showed obstructive pulmonary features. Our results show a tendency of RA as a systemic inflammatory condition to attack pulmonary tissues as an early common extra articular target of the disease process. A comparable data has been reported by a study in which abnormal pulmonary function test has been observed in $30 \%$ of 246 RA patients. ${ }^{[17]}$ In addition, the overall patients data compared to the matched control group shows a significant decrease in the average FEV1 and FVC among RA patients with no significant changes in FEV1/FVC. These results indicate a restrictive lung pattern of interstitial lung disease that does not affect the bronchial resistance and tone but lung volumes. Our finding of abnormal pulmonary function tests in RA patients rises the question of time at which pulmonary tissues are attacked by RA autoantibodies. It has been found by data from other studies that systemic inflammation and autoimmunity may precede the presentation of RA as a classifiable disease. ${ }^{[18]}$ Deane et al 2010 found elevated levels of autoantibodies, cytokines and chemokines in a stored blood samples obtained from 73 military cases with seropositive RA in the preclinical stage of RA. ${ }^{[19]}$ Whereas van de Sande et al 2011 could not find any histological or magnetic resonance imaging (MRI) evidence of synovial inflammation in the knee of individuals with seropositive RA-related autoantibodies without 
clinically-evident synovitis. ${ }^{[20]}$, Demoruelle and his colleagues recently observed a higher prevalence of inflammatory airways disease using computed tomographic imaging in arthritis-free with seropositive RA-related autoantibodies compared to a seronegative matched controls. ${ }^{[21]}$ In a consistent cross sectional study for characterizing pulmonary involvement in 63 RA patients by spirometer, $\mathrm{x}$ ray and high resolution computed tomography (HRCT) of thorax, Mohd et al 2009 found a restrictive pattern of pulmonary disease in $66.7 \%$ of the patients. The most common HRCT findings were reticulation (46\%), ground glass opacities $(38.1 \%)$ and bronchiectasis $(28.6 \%){ }^{[22]}$ The limitations in our study includes small sample size, the inability to show the disease activity in correlation with pulmonary involvement by using rheumatoid factor, anticitrullinated peptides (CCP) antibody levels and $\mathrm{x}$-ray changes as well as diffusion lung capacity for carbon monoxide $\left(\mathrm{DL}_{\mathrm{CO}}\right)$ test as an indicator of the severity of respiratory membrane involvement.

In conclusion, the lung is a potential target organ of the RA inflammatory disease process that could precede the onset of the synovial joint involvement. Different pattern of pulmonary function abnormalities could be manifested in RA patients and a restrictive pattern represents the most common feature. Spirometry test is indicated as a baseline assessment and follow up for RA patient to enhance early detection and management of the pulmonary involvement.

\section{REFERENCE}

1. Milind P. How to live with rheumatoid arthritis??? International Research Journal of Pharmacy 2012 Mar; 3(3): 115-121.

2. Silman AJ, Pearson JE. Epidemiology and genetics of rheumatoid arthritis. Arthritis Res 2002; 4(Suppl 3): S265-272.

3. Al-Rawi ZS, Alazzawi AJ, Alajili FM, Alwakil $R$. Rheumatoid arthritis in population sample in IRAQ. Ann Rheum Dis 1978; 37(1): 73-75.
4. Del Puente A, Knowler WC, Pettitt DJ, Bennett PH. High incidence and prevalence of rheumatoid arthritis in Pima Indians. Am J Epidemiol 1989 Jun; 129(6):1170-1178.

5. Shichikawa $K$, Inoue $K$, Hirota $S$, Maeda A, Ota $H$, Kimura $M$, sujimoto $M$. Changes in the incidence and prevalence of rheumatoid arthritis in Kamitonda, Wakayama, Japan, 19651996. Ann Rheum Dis 1999 Dec; 58 (12): 751-756.

6. Bajocchi G, La Corte R, Locaputo A, Govoni M, Trotta F. Elderly onset rheumatoid arthritis: clinical aspects. Clin Exp Rheumatol 2000; 18(4 Suppl 20): S49-50.

7. Cimmino MA, Salvarani C, Macchioni P, Montecucco C, Fossaluzza V, Mascia MT, et al. Extra-articular manifestations in 587 Italian patients with rheumatoid arthritis. Rheumatol Int 2000; 19(6): 213-217.

8. Dawson JK, Fewins HE, Desmond J, Lynch MP and Graham DR. Fibrosing alveolitis in patients with rheumatoid arthritis as assessed by high resolution computed tomography, chest radiography, and pulmonary function tests. Thorax 2001; 56(8): 622-627.

9. Bilgici A, Ulusoy H, Kuru O, Celenk C, Unsal $M$, Danaci $M$. Pulmonary involvement in rheumatoid arthritis. Rheumatol Int 2005; 25(6): 429-435.

10. Lioté H. Pulmonary manifestation of rheumatoid arthritis. Rev Mal Respir 2008 Oct; 25(8): 973-988.

11. Lee HK, Kim DS, Yoo B, Seo JB, Rho JY, Colby TV, Kitaichi M. Histopathologic pattern and clinical features of rheumatoid arthritisassociated interstitial lung disease. Chest 2005 Jun; 127(6): 2019-2027.

12. Yunt ZX, Solomon JJ. Lung disease in rheumatoid arthritis. Rheum Dis Clin North Am 2015; 41(2): 225-236.

13. Amital A, Shitrit D, Adir Y. The lung in rheumatoid arthritis. Presse Med 2011; 40(1 Pt 2): e31-48.

14. Aletaha D, Neogi T, Silman AJ, Funovita J, Felaon DT, Bingham CO, et al. 2010 Rheumatoid Arthritis Classification Criteria. Arthritis \& Rheumatism; 62 (9): 2569-2581.

15. Dan LL, Anthony SF, Denis LK, Stephen LH, Jameson JL, Joseph L. Harrison's principles of internal medicine 18th edition. McGraw-Hill, New York, 2012. Page 2086.

16. Van Vollenhoven RF, McGuire JL. Estrogen, progesterone, and testosterone: can they be 
used to treat autoimmune diseases? Cleve Clin J Med 1994; 61(4): 276-284.

17. Kawassaki AM, Pereira DA, Kay FU, Laurindo IM, Carvalho CR, Kairalla RA. Pulmonary involvement in rheumatoid arthritis: evaluation by radiography and spirometry. J Bras Pneumol 2015; Jul-Aug; 41(4): 331-342.

18. Demoruelle MK, Deane KD, Holers VM. When and where does inflammation begin in rheumatoid arthritis? Curr Opin Rheumatol 2014; 26(1): 64-71.

19. Deane KD, O'Donnell CI, Hueber W, Majka DS, Lazar AA, Derber LA, et al. The number of elevated cytokines and chemokines in preclinical seropositive rheumatoid arthritis predicts time to diagnosis in an age-dependent manner. Arthritis Rheum 2010; 62(11): 31613172.
20. Van de Sande MG, de Hair MJ, van der Leij C, Klarenbeek PL, Bos WH, Smith MD, et al. Different stages of rheumatoid arthritis: features of the synovium in the preclinical phase. Ann Rheum Dis 2011; 70(5): 772-777.

21. Demoruelle MK, Weisman MH, Simonian PL, Lynch DA, Sachs PB, Pedraza IF, et al. .Brief report: airways abnormalities and rheumatoid arthritis-related autoantibodies in subjects without arthritis: early injury or initiating site of autoimmunity? Arthritis Rheum 2012; 64(6): 1756-1761.

22. Mohd Noor N, Mohd Shahrir MS, Shahid MS, Abdul Manap $\mathbf{R}$, Shahizon Azura AM, Azhar Shah S. Clinical and high resolution computed tomography characteristics of patients with rheumatoid arthritis lung disease. Int J Rheum Dis 2009; 12(2): 136-144. 